\title{
Je konečně na řadě primárni prevence kardiovaskulárních onemocnění? - editorial
}

\author{
Eliška Sovová \\ Klinika tělovýchovného lékařství a kardiovaskulární rehabilitace LF UP a FN Olomouc

\begin{abstract}
Komentář k | Editorial on
Mateřánková $\mathrm{M}$ et al. Rizikové faktory kardiovaskulárních onemocnění u potomků nemocných po časném infarktu myokardu. Vnitř Lék 2017; 63(6): 398-402.
\end{abstract}

Kardiovaskulární mortalita je stále vedoucí prríčinou smrti ve vyspělých státech světa a znamená stále se zvyšující finanční nároky na zdravotnickou péči. Populační a individuální preventivní opatření ke snížení rizikových faktorů by měla vést ke snížení výskytu těchto onemocnění.

Pokud si položíme otázku, zda se opravdu v naší klinické praxi věnujeme primární prevenci, odpověd' bude asi rozpačitá. Kolik pracovišt' opravdu aktivně vyhledává tyto ohrožené osoby s cílem nějaké smysluplné intervence?

Zdraví príbuzní osob s kardiovaskulárním onemocněním se jako vhodná intervenovaná skupina přímo nabízejí, a to ze dvou pohledů. Na jedné straně jsou to genetické faktory, které riziko onemocnění zvyšují, a na druhé straně jsou to environmentální (behaviorální) faktory, které mohou s rodinným výskytem těchto onemocnění souviset.

Bylo publikováno již více studií u dvojčat a rodinných příslušníků, které potvrzují signifikantní genetickou komponentu variability rizikových faktorů kardiovaskulárních onemocnění [1]. V recentní studii finských autorů u 132771 dvojčat bylo prokázáno, že u monozygotních dvojčat bylo relativní riziko pro vznik kardiovaskulárních onemocnění $1,49(95 \% \mathrm{Cl} 1,40-1,57)$, pro vznik cévní mozkové příhody 1,81 (95\% Cl 1,54-2,09), nejvyšší riziko bylo prokázáno pro vznik hemoragické cévní mozkové př́íhody 3,53 (95\% Cl 2,01-5,04) [2].

Environmentální faktory se na vzniku rizikových faktorů kardiovaskulárních onemocnění podílejí nemalou měrou. Jejich sledování je snad ještě náročnější než provádění genetických studií. $V$ recentním systematickém review, které se věnovalo vztahům mezi „nezdravým" dietním chováním a výskytem kardiometabolických rizikových parametrů (jako např. glykemie, inzulin, lipidový profil, homocystein a další) u dětí a adolescentů byla prokázána jejich pozitivní asociace [3]. Nicméně po adjustaci na některé proměnné byl tento vztah méně významný nebo se neprokázal. Autoři však upozorňují na některé faktory, které výsledky ovlivňují, jako je validace dotazníkového šetření, nedostatky $v$ hodnocení složení stravy. Nicméně v závěru zdůrazňují, že je třeba pokračovat $v$ těchto studiích, a to ze- jména v souvislosti s nárůstem nadváhy a obezity mezi dětmi a adolescenty.

V posledních evropských doporučeních pro prevenci kardiovaskulárních onemocnění [4] je rodinná anamnéza hodnocena jako jednoduchý a levný nástroj na upřesnění vypočítaného kardiovaskulárního rizika a doporučuje se používat hlavně v hraničních případech, kdy se rozhodujeme o možné větší intervenci rizikových faktorů. Stran genetického testování jsou doporučení zdrženlivá a nedoporučují rutinní genetické testování.

V tomto čísle časopisu Vnitřní lékařství je publikován článek z plzeňského kardiologického pracoviště, který se věnuje vyšetření příbuzných osob s kardiovaskulárním onemocněním. Ukazuje nejen to, že rizikové faktory jsou u těchto osob zvýšeny, ale hlavně možnou metodiku oslovení blízkých príbuzných [5]. Podobnou metodiku jsme použili i my u našeho souboru prvostupňových příbuzných [6], ale ještě jsme ji rozšírili o intervenci rizikových faktorů a sledovali jsme pozitivní vliv této intervence po roce.

Na základě těchto poznatků je třeba dále rozvíjet hlavně spolupráci kliniků a praktických lékařů, protože právě lékaři v první linii by měli hrát v této péči nezastupitelnou úlohu.

\section{Literatura}

1. Rankinen T, Sarzynski MA, Ghosh S et al. Are There Genetic Paths Common to Obesity, Cardiovascular Disease Outcomes, and Cardiovascular Risk Factors? Circ Res 2015; 116(5): 909-922. Dostupné z DOI: <http://dx.doi.org/10.1161/CIRCRESAHA.116.302888>.

2. Silventoinen $\mathrm{K}, \mathrm{Hjelmborg} \mathrm{J}$, Möller $\mathrm{S}$ et al. Family aggregation of cardiovascular disease mortality: a register-based prospective study of pooled Nordic twin cohorts. Int J Epidemiol 2017. Dostupné z DOI: <http://dx.doi.org/10.1093/ije/dyx012>.

3. Rocha NP, Milagres LC, Longo GZ et al. Association between dietary pattern and cardiometabolic risk in children and adolescents: a systematic review. J Pediatr (Rio J) 2017; 93(3): 214-222. Dostupné z DOI: <http://dx.doi.org/10.1016/j.jped.2017.01.002>.

4. Piepoli M, Hoes AW, Agewall S et al. 2016 European Guidelines on cardiovascular disease prevention in clinical practice: The Sixth Joint Task Force of the European Society of Cardiology and Other Societies on Cardiovascular Disease Prevention in Clinical Practice (constituted by representatives of 10 societies and by invited experts)Developed with the special contribution of the European Association for 
Cardiovascular Prevention \& Rehabilitation (EACPR). European Heart Journal 2016; 37(29): 2315-2381. Dostupné z DOI: <http://dx.doi. org/10.1093/eurheartj/ehw10>.

5. Mateřánková $M$, Karnosová $P$, Mlíková Seidlerová J et al. Rizikové faktory kardiovaskulárních onemocnění u potomků nemocných po časném infarktu myokardu. Vnitř Lék 2017; 63(6): 398-402.

6. Sovova E, Kaletova M, Stejskal D et al. Intervention for cardiovascular risk factors decreases adipocyte fatty acid binding protein levels in males- a pilot study. Cent Eur J Med 2014; 9(1): 28-33. Dostupné z DOI: $<$ http://dx.doi.org/10.2478/s11536-013-0231-0>. prof. MUDr. Eliška Sovová, Ph.D., MBA $\checkmark$ Eliska.Sovova@fnol.cz

Klinika tělovýchovného lékařství a kardiovaskulární rehabilitace LF UP a FN Olomouc

www.fnol.cz

Doručeno do redakce 15. 7. 2017

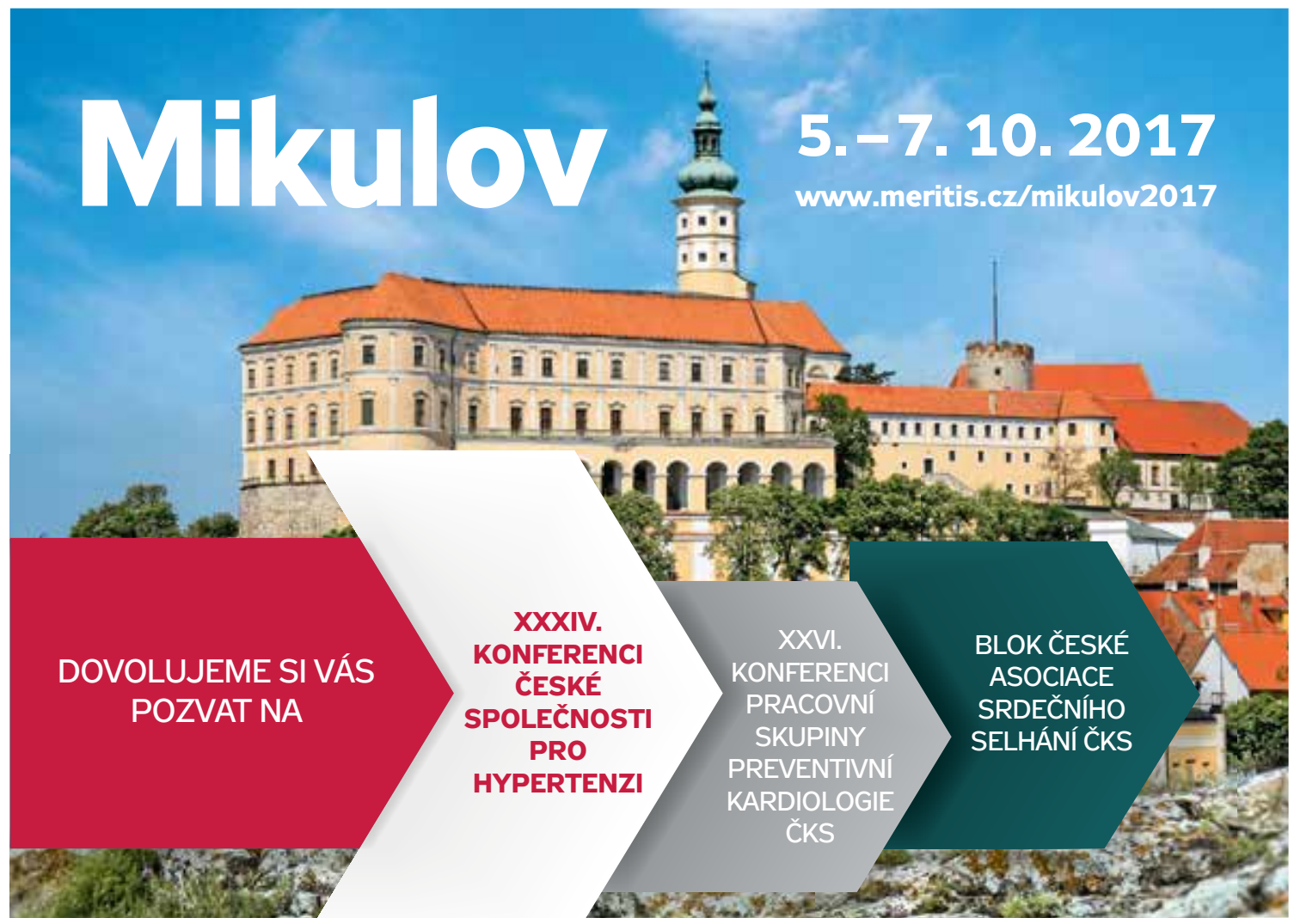

